\title{
SCIENTISTS IN GOVERNMENT SERVICE IN BRITAIN
}

\author{
SPECIAL PROMOTIONS
}

TURTHER special posts have been created in the I Civil Service, under provisions included in the White Paper on the Scientific Civil Service (Cmd. 6679 ; 1945), to provide for the promotion of individual research workers of exceptional merit. They include the following :

\section{Deputy Chief Scientific Officers}

DR. R. D'E. Atrkinson. Dr. Atkinson was appointed chief assistant at the Royal Observatory, Greenwich, in 1937, and in 1940 was loaned for degaussing work under the Admiralty. He is now at the Royal Greenwich Observatory, Herstmonceux. Dr. Atkinson is well known for his pioneer work on the mechanism of generation of stellar energy, but has in recent years turned his attention to the problems of positional and meridian astronomy, and has devoted considerable attention to the problem of flexure in transit instruments, this being a recognized source of error in accurate meridian work. He has designed a mirror transit which it is proposed to make for the Royal Greenwich Observatory.

Mr. H. B. Howard. Mr. Howard joined the Scientific Civil Service in 1916. He has had long and varied experience in aircraft research, and since 1945 he has been assistant director of research on aircraft structures at Ministry of Supply Headquarters, in which capacity he has personally planned and co-ordinated aircraft structural research sponsored by the Ministry of Supply at the universities and in the aircraft industry. He is particularly distinguished as originator of the 'Howard diagram', for his early and far-sighted organization of research on flutter and vibration at the Royal Aircraft Establishment and for many substantial personal contributions to modern aircraft structural research.

Dr. G. H. Metson. Dr. Metson joined the Post Office in 1933. Since 1946 he has led a team developing long-life, high-slope, pentode valves for submerged repeaters. His studies of oxide-cathode valves have led to a proper understanding of the causes of failure and to a production line employing novel techniques and rigorous testing and selection. In particular, passive platinum replaces active nickel for the cathode core; the growth of interface impedance and the excessive production and evaporation of metallie barium are thereby avoided and the means for activating and retaining activation on the passive core have been successfully found and explained. Subsidiary studies of other necessary materials and vacua have been made. His valves are in use in the Newfoundland to Nova Scotia section of the Trans. Atlantic Telephone Cable.

\section{Senior Principal Scientific Officers}

Mr. I. M. Davinson. Mr. Davidson works at the National Gas Turbine Establishment, where he has been primarily concerned with research in the aerodynamics of engines and has made notable contributions to the theory of supersonic flow and super. sonic compressors, his recent work on the use of the jet flap to improve aircraft performance being particularly outstanding.
Dr. K. H. Dowtsch. Dr. Doetsch is at the Roval Aircraft Fistablishment. Since 1953 he has been in charge of research and development of auto-pilots, autostabilization gear and powered controls.

Dr. L. Essen. Since Dr. L. Essen joined the National Physical Laboratory in 1929 he has been concerned with precise microwave measurements, in particular with the measurement of frequency and time. Recently he has developed a frequency standard, based on a resonance of the cæesium atom, which offers the possibility of a more permanent, convenient and accurate fundamental time-standard than the astronomical standards hitherto used.

DR. F. A. Isherwood. Since joining the Low Temperature Research Station, Cambridge, Dr. Isherwood has investigated the chemistry and biochemistry of the cell wall of plants and the soluble constituents of the cytoplasm. Recently, he has been studying the contribution which lignin and other phenolic substances make to the physical properties of the cell wall.

Dr. M. S. Longuet-Higains. Dr. LonguelHiggins joined the National Institute of Oceanography in 1954. Hitherto noted primarily for his important theoretical studies, he is at present particularly concerned with allied experimental investigations on the generation and changes in the characteristics of ocean waves and with the propagation of storm surges.

Dr. L. W. Mapson. At the Low Temperature Research Station, Cambridge, Dr. Mapson and Dr. Isherwood have made notable contributions to the knowledge of the role of ascorbic acid in plants and animals. Dr. Mapson's studies have been particularly concerned with the biological synthesis of vitamin C in plants and animals, the conditions of its stability and its role as a component of the respiratory enzyme system.

Dr. H. Sмrтh. Dr. Smith has worked at the Microbiological Research Fstablishment since 1947. $\mathrm{He}$ has done outstanding research on the virulenceenhancing action of mucin and on the chemical basis of the virulence of the anthrax bacillus.

Mr. J. K. ZBrozeK. Mr. Zbrozek has been working at the Royal Aircraft Establishment on the influence of atmospheric gusts on the flight dynamics of aircraft, using the 'power spectrum' method.

Mr. H. Ziebland. Since $1946 \mathrm{Mr}$. Ziebland has worked at the Explosives Research and Development Hstablishment, where he has applied engineering skill and theoretical and experimental ability in physics to problems of heat transfer, low-temperature research and thermal conductivity.

Similar promotions have been made by the United Kingdom Atomic Energy Authority as follows :

\section{Deputy Chief Scientific Officer}

Dr. B. B. Kinsey. Dr. Kinsey became associated with atomic energy in 1942 when he joined the research team working at the Cavendish Laboratory, Cambridge, under the Directorate of Tube Alloys. When part of this project was transferred to Montreal, he joined the group engaged in the determina- 
tion of the basic data required for nuclear reactors, and then, a year later, moved to the newly founded laboratory at Chalk River, Ontario. There Dr. Kinsey did notable work on the gamma-rays produced by neutron capture. In 1954 he spent a year at the Radiation Laboratory of the University of California as a guest of the United States Atomic Energy Commission, studying the interactions of high-energy protons with nuclei. Since $1955 \mathrm{Dr}$. Kinsey has held a special research appointment at the Atomic Energy Research Establishment at Harwell.

\section{Senior Principal Scientific Officers}

Dr. G. C. BARKer. Dr. Barker is in charge of a small electrochemistry section in the group under Dr. E. Glueckauf. He has been responsible for the development of the square-wave polarograph which represents a major advance in polarography. $\mathrm{He}$ has studied the electrochemistry of ion-exchange resins and has recently applied the square-wave polarograph to the determination of ions in molten salts.

Mr. W. B. Hall. Mr. W. B. Hall, of the Atomic Energy Authority Industrial Group, is in charge of experimental engineering in the Research and Development Laboratories at Windscale in Cumberland. He has worked on heat transfer and associated problems in reactors with both gaseous and liquid metal coolants.

Mr. J. D. LAwson. Mr. Lawson is distinguished for his work in electron physics. He has studied the behaviour of electron beams in accelerators and the radiation from targets bombarded by high-energy electrons, and has led a team in the development of new types of high-power klystron valves operating in the microwave region. He is at present head of a section of the Accelerator Group at Harwell, in charge of long-term research on particle dynamics in unusual configurations of electric and magnetic fields, with the help of electronic and mechanical analogues.

\section{NEUROCHEMISTRY}

\section{INTERNATIONAL SYMPOSIUM IN AARHUS}

$\mathrm{T}$ HE word 'neurochemistry' is coming to mean something rather more than the bare chemistry of nervous tissues. At the second International Neurochemical Symposium recently held at Aarhus, Denmark, the discussion ranged freely from electron microscopy to problems of nervous transmission and drug action. While the metabolism of nervous tissues formed the central theme, the programme reflected a growing appreciation of the significance of biochemistry in relation to the morphology and function of the nervous system.

In the opening session, Prof. F. O. Schmitt, of the Massachusetts Institute of Technology, gave an admirably lucid account of the molecular structure and properties of the nerve cell membrane. He reported that isolated sections of nerve membrane obtained from squid giant axons show a relatively high metabolic activity in vitro, suggesting that the membrane may account for a large part of the metabolism of the whole cell. In a discussion of the nature and structure of the myelin sheath of medullated nerve fibres, it appeared that the new evidence obtained with the electron microscope agrees with that derived from X-ray studies in supporting the view that the myelin sheath is made up of concentric layers of a double membrane. According to the 'jelly-roll' hypothesis, the double membrane grows out from the point of contact of nerve axon and Schwann cell, and wraps itself around the axon; but it is difficult to apply this hypothesis to the myelin in the central nervous system. Mr. G. B. David (Cardiff) reviewed the structure of the synaptic terminations, of which some two thousand can be counted on the surface of the large ganglion cells of the brain. He presented evidence that some of the nerve endings terminate in fine filaments which enter the post-synaptic ganglion cells. Récent work on the mechanism of nervous conduction was described by Dr. R. D. Keynes (Cambridge), and the relation of phospholipids to the binding and transport of cations was discussed by Dr. J. Folch-Pi (Waverley). It appears that the phospholipids may be intimately concerned in the operation of the 'sodium pump'.

In a session devoted to the histochemistry and cytochemistry of nervous tissues, Prof. O. H. Lowry (St. Louis) described the spectacular work coming from his laboratory on the quantitative distribution of enzymes in individual ganglion cells, obtained by micromanipulation from different parts of the brain. Some enzymes are evenly distributed throughout the cytoplasm and others are located especially at the cell surface. Asked by Dr. M. (T. Larrabee (Baltimore) if he had yet made measurements on individual mitochondria, Prof. Lowry replied: "No. But there is another Symposium in two years !". Cytological aspects of nucleic acid metabolism were reviewed by Prof. L. Einarson (Aarhus), who discussed in particular the changes associated with functional activity of the neurone. Dr. J. E. Edström (Gothenburg) reported a very outstanding piece of work on the purine-pyrimidine analysis of the ribonucleic acid in individual nerve cells of the hypoglossal nucleus, using a combination of chromatography on single cellulose fibres and ultra-violet microspectrophotometry.

Other sessions dealt with the general metabolism of the brain in vivo and of isolated ganglia, brain slices and peripheral nerve. The role of coenzymes in group activation was reviewed by Prof. F. Lipmann (Boston), and Prof. H. McIlwain (London) contributed a paper on the speed of chemical changes in the brain. Prof. H. Waelsch (New York) reviewed the nitrogen metabolism of the brain and described new results with radioactive lysine which confirm the earlier work with radioactive methionine in showing the high metabolic activity of the proteins. The rate of incorporation of labelled amino-acids is greatest in the microsomes, and Dr. D. Clouet (Cardiff) reported the isolation from the microsomes of a highly active nucleoprotein which accounts for a large part of the amino-acid turnover in the proteins of the brain. Lipid metabolism was discussed by Prof. R. J. Rossiter (Ontario) and Prof. E. Klenk (Cologne). Prof. F. Lynen (Munich) contributed a review of the role of acetyl-coenzyme $\mathbf{A}$ in the synthesis of fatty acids.

In the closing session, devoted mainly to the biochemistry and physiology of pharmacologically active compounds and drugs, Dr. W. Feldberg (London) gave an account of the role of acetylcholine in the central nervous system. Dr. M. Vogt (Edinburgh) described recent work on the distribution of adrenaline and noradrenaline in the brain, and concluded that the tranquillizing drug reserpine appears to act by 